radioactive substances in diet are given in periodic reports by the Agricultural Research Council's Radiobiological Laboratory, the most recent of which was published in May, 1962. This report on drinking water is the fourth on this subject in the Government's monitoring programme, and states that well water remains virtually free from radioactivity. Impounded waters generally have higher levels than river water.

\section{U.S. Committee on Extension to the Standard Atmosphere}

THE co-chairmen of the above U.S. national effort, described in Nature of July 14, p. 133, are $\mathrm{Mr}$. Maurice Dubin, National Aeronautics and Space Administration, Mr. Norman Sissenwine, Geophysics Research Directorate, Air Force Cambridge Research Laboratories, and Dr. Harry Wexler, U.S. Weather Bureau.

\section{University and College News:}

Birmingham

The College of Advanced Technology, Birmingham, was transferred to an independent Board of Govern. ors as from April 1, 1962, and the latest report of the principal, Dr. P. F. R. Venables, covers the period September 1960-March 1962 (Pp. 40. Birmingham: College of Advanced Technology, 1962). During this period 220 students were admitted to the Associateship at the Presentation Ceremony in 1961, and 264 Associates were admitted in March 1962. Grants for research were received in the form of the Wilmot Breeden and the Lucas Research Fellowships and a Ministry of Aviation Research Fellowship. A Research Fellow has been appointed in the Department of Industrial Administration for a research project to investigate end-on arrangements in the development of sandwich courses, which was established with a grant of $£ 6,700$ from the Nuffield Foundation. One senior Research Fellow and two research assistants were appointed to a research unit established with a grant of $£ 28,580$ from the Department of Scientific and Industrial Research to investigate social factors affecting relations and individual performance in factories. Of 5,359 students in the session $1960-61,1,264$ were full time, 2,072 in parttime day courses and 2,023 in evening courses only; for the past session 1961-62 the corresponding figures were $1,386,1,605$ and 1,991. Enrolments in sandwich courses totalled 838,282 being in mechanical and production engineering and 250 in electrical engineering. In 1961-62 the total increased to 956 .

\section{Cambridge}

THe following election 10 followships ('Title $A$ ) at Churchill College have been announced: Dr. J. D. C. MeConnell, of Fitzwilliam House (University lecturer in mineralogy, College lecturer in mineralogy); F. H. MeClintock, of Trinity College (assistant diroctor of research in criminology, Colloge lecturer and director of studies in law); A. A. Sinclair (Collego lecturer and director of studies in history).

\section{Oxford}

Prof. R. PEIERLs, professor of mathematical physies in the University of Birmingham, has been appointed to the Wykeham professorship in physics with effect from October 1. Dr. V. Zussman has been elected to the readership in mineralogy and will take up his appointment in the academic year 1962-63. The following appointments to lectureships have been announced: Dr. D. A. Edwards, A. W. Ingleton, J. D. Murray (mathematics); F. O. MacCallum (virology); D. J. Roaf (theoretical physics); Dr. W. E. Parry (physics).

\section{Announcements}

Air Commodore B. Samson, has been appointed director, Aircraft Mechanical Engineering Equipment Research and Development, with effect from August 13. Previously he was senior technical staff officer with Near East Airforce.

A sYMPOSIUM on "Fungi and their Metabolites" will be held by the Plant Phenolics Group and the British Mycological Society at the School of Pharmacy, Brunswick Square, London, W.C.1, during October 1-2. Further information can be obtained from Dr. J. G. Manners, Department of Botany, the University, Southampton.

The Institute of Biology is organizing a symposium on "Colour and Life" to be held at the Harkness Hall, Birkbeck College, during September 20-21. The symposium is open to members and non-members of the Institute; for the latter, however, there will be a fee of 21s. Further information can be obtained from the General Secretary, Institute of Biology, 41 Queen's Gate, London, S.W.7.

A symposrum, organized by the Nutrition Society, will be held on "Assessment of Nutritional Status in Man" at the Lecture Theatre, Chemistry Building. Meston Walk, Old Aberdeen, on September 29. Further information can be obtained from the honorary secretary of the Scottish Group of the Nutrition Society, Dr. D. G. Armstrong, the Hannah Dairy Research Institute, Ayr, Scotland.

A CONFERENCE of European comparative endocrinologists will be held in London at the Rooms of the Zoological Society during September 20-22. Further information can be obtained from the convonors. Prof. H. Heller, Department of Pharmacology and Practical Pharmacy, the Univorsity, Bristol 8, and Prof. E. J. W. Barrington, Department of Zoology. the University, Nottingham.

The Third International Machine Tool Design and Research Conference will be held at the Department of Mechanical Engineering, University of Birmingham, during September 24-28. Further information can be obtained from the Organizing Secretary of the Third International Machine Tool Design and Research Conference Dopartment of Mechanical Enginecring, the University, Edgbaston, Birmingham 15.

The Faradav Socioty is organizing a general disc:ission on "High Resolution Nuclear Magnetic Resonance" at the University of Oxford during Septembor 17-19. The discussion will be divided into (1) nuclear magnetic resonance in diamagnetic materials; (2) nuclear magnetic resonance in paramagnetic materials; (3) applications to the determination of molecular structure; (4) applications to the study of kinetic processes. Further information ean be obtained from the Faraday Society, 6 Gray's Inn Square, London, W.C.1. 